\title{
DIRECT COMPATIBILITY TESTING
}

\author{
BY
}

\author{
N. A. F. YOUNG
}

From St. Margaret's Hospital, Epping

(RECEIVED FOR PUBLICATION NOVEMBER 29, 1957)

Despite the rapid development of knowledge it still remains fundamental that mistakes within the $\mathrm{ABO}$ and Rhesus systems are responsible for virtually all fatal mismatched transfusions. It therefore cannot be too highly stressed that the careful preliminary grouping of the bloods of all patients for transfusion is of prime importance, irrespective of whether there is a previous record of their blood group or not. This should always be regarded as an essential part of any cross-marching routine, and in urgent cases Stratton's (1955) "sandwich technique" is highly recommended for rapid $\mathrm{Rh}$ typing.

The " emergency crossmatch" presents a problem, and the vital question which needs answering is: What can safely be accepted as the minimum incubation period which will not impair the efficiency of the particular compatibility tests being used ?

The concept of gradual red cell sensitization progressively increasing with time is fallacious. Antigen-antibody union takes place quite rapidly, and, after a relatively short time, which varies slightly with different methods, further prolonged incubation does not increase the sensitivity or render the detection of very weak antibodies significantly more likely. This is shown by the investigations which are detailed later, and the results obtained by Lewis and Chown (1957) using a 10-minute albumin agglutination technique substantiate this view.

The ideal cross-matching technique should provide a simple, easily performed procedure which is not only highly sensitive but which at the same time will yield reliable results when used routinely.

Certain practical points have been investigated, and on the basis of the findings obtained a simple direct matching procedure, which is not timeconsuming but still combines the advantages of both trypsin and Coombs testing, is recommended.
The Indirect Coombs Test (A.H.G.)

Minimum Incubation Period for Reliable Results.Twenty-five sera were tested in triplicate, all tests being standardized so that 4 vol. of serum was used to sensitize $1 \mathrm{vol}$. $50 \%$ suspension of washed packed Group $\mathrm{O} \mathrm{R}_{1} \mathrm{r}$ cells. Incubation periods of 10,30 , and 120 minutes were used. The test sera ranged in potency from extremely weak ones, giving only a trace albumin agglutination, to strong sera with albumin titres up to $1 / 128$.

Readings were made by the usual tile method and the reactions timed with a stopwatch.

If no agglutination had occurred at the end of seven minutes a negative result was recorded.

All tests gave positive results although some of the "10-minute incubation" ones were rather weak. The usual reaction in these cases was a fine granularity first appearing between two and four minutes, gradually becoming clear cut, but still tending to retain a homogeneous pink background at the end of seven minutes.

The reactions of the " 30 -minute incubation tests" were all strong and clear cut. They were as good as those obtained by longer incubation and in a surprising number of instances they were somewhat better defined than the corresponding two-hour agglutinations.

There seems little doubt that the optimal incubation time for complete sensitization is much shorter than is generally appreciated. Using the indirect Coombs for direct compatibility testing, it is considered that an incubation time of 30 minutes is adequate. In an emergency, a 10- or 15-minute Coombs test is an extremely valuable procedure which is capable of detecting very weak sensitization.

Effect of Variable Serum-cell Ratios on Sensitivity of Coombs Reaction.- - The Coombs reactions obtained after sensitizing red cells for a standard incubation period of 30 minutes using serum : cell 
ratios varying from $2: 1$ to $10: 1$ have shown no significant differences. It is therefore apparent that, although theoretically it might be expected that the addition of a greater volume of serum would increase the amount of antibody available for each red cell, in practice the effect is minimal. The probable explanation of this is the fact that, although the total amount of antibody is thereby increased, the actual concentration of antibody molecules per unit volume of serum remains precisely the same.

A Modified Tube Technique.-. With the development of a simplified trypsin-saline and trypsinCoombs compatibility routine in mind, the results of the Coombs test performed in tubes were compared with those obtained by the more generally adopted tile method. For this comparative trial a series of very weak albumin agglutinating anti-Rh sera was used. A parallel series of tests was made by the tile method and by a modified tube technique described here.

Method.-Unit volumes of $10 \%$ washed test cell suspensions were sensitized with $4 \mathrm{vol}$. of serum. Tests were set up in triplicate for incubation periods of 10 , 30 , and 120 minutes respectively. After incubation they were washed three times in saline, the final supernatant being completely removed so as to leave a dry button of red cells. Three drops of suitably diluted A.H.G. reagent were added to each tube. The tubes were vigorously shaken to mix the cells, allowed to stand at bench temperature for two minutes, and then centrifuged at 1,500 r.p.m. for two minutes. Readings were made by gently resuspending the cells and microscoping if necessary.

Results.-In most instances the results by tile and tube techniques were similar, but in some cases the tube test gave clearer results and was distinctly more sensitive for the detection of minimal sensitization. The results obtained in four antenatal patients whose sera contained very weak antibodies are shown in Table I, and it will be noted that in one case the tile test was negative whereas the tube

TABLE I

RESULTS IN TILE AND TUBE TESTS ON FOUR ANTENATAL SERA

\begin{tabular}{|c|c|c|c|c|}
\hline \multirow{2}{*}{$\begin{array}{c}\text { Serum } \\
\text { No. }\end{array}$} & \multirow{2}{*}{ Method } & \multicolumn{3}{|c|}{ Incubation Time } \\
\hline & & $10 \mathrm{Min}$. & $30 \mathrm{Min}$. & $120 \mathrm{Min}$. \\
\hline \multirow[t]{2}{*}{1} & Tile & $\begin{array}{l}\text { Uniform fine } \\
\text { granularity }\end{array}$ & $+\div$ & $+\cdots$ \\
\hline & Tube & sid & $\cdots \cdots$ & $\cdots-$ \\
\hline 2 & $\begin{array}{l}\text { Tile } \\
\text { Tube }\end{array}$ & $\begin{array}{l}\text { Neg. } \\
\text { Weak - }\end{array}$ & $\begin{array}{c}\text { Neg. } \\
\text { Weak - }\end{array}$ & $\begin{array}{c}\text { Neg. } \\
\text { Weak }\end{array}$ \\
\hline \multirow[t]{2}{*}{3} & Tile & Neg. & $\begin{array}{l}\text { Very weak } \\
\text { granularity }\end{array}$ & Weak - \\
\hline & Tube & Weak - & $\ldots \ldots$ & $\cdots \cdots$ \\
\hline 4 & $\begin{array}{l}\text { Tile } \\
\text { Tube }\end{array}$ & Neg. & Doubtful - & Weak - \\
\hline
\end{tabular}

test was weakly positive. In sera 2 and 3 the tile method was negative at 10 minutes whereas the tube showed positive agglutination after this period of incubation.

Further experience in a large number of controlled tests has led to the conclusion that for routine usage the tube technique gives more consistent results and is distinctly more sensitive than the tile method. There does not appear to be any tendency to false agglutination and in all cases the negative controls have shown no trace of agglutination.

Stability of Stored Diluted A.H.G. Serum.--The instability of A.H.G. serum and its inability to withstand repeated thawing and refreezing are wellrecognized drawbacks which can cause anomalous results. Mollison (1951) states: "Attention must be drawn to the fact that anti-human globulin sera diluted in saline lose their potency very rapidly even when stored at $-20^{\circ} \mathrm{C}$. The diluted reagent should be prepared freshly each day. ...' This has not been the author's experience nor that of his colleague Dr. F. Marsh (1957), to whom he is indebted for the results of a two-year trial using stored diluted antiglobulin sera. Diluted serum stored at $-20^{\circ} \mathrm{C}$., placed in a water-bath for a couple of minutes and used for testing, then immediately replaced in the refrigerator, will withstand thawing for at least seven times without significant loss of its ability to agglutinate weakly sensitized red cells. Such diluted reagent has been kept and used regularly once daily for periods up to 10 to 14 days without deterioration. Reagent made up and used at weekly intervals remained stable and still strongly agglutinated sensitized cells when finally tested for the seventh time after being stored for eight weeks.

Initially storage results were not constant or reliable, and it was noted that odd A.H.G. sera would deteriorate much more rapidly and unexpectedly, as Mollison states. Experience showed that these failures were attributable to two causes. In the first place, the extreme importance of avoiding any trace of globulin contamination in the saline used as the diluent had not been sufficiently appreciated. Secondly, it was found that if the A.H.G. serum from which the diluted reagent was made had itself began to deteriorate, then the diluted reagent would be quite unstable. Provided meticulous care is taken in the preparation of the diluted reagent from a fully potent A.H.G. serum which has not started to deteriorate, then this reagent can be stored at $-20^{\circ} \mathrm{C}$. for long periods. It will withstand thawing up to at least seven times; nor does there appear to be any loss of specificity and false agglutinations have not been encountered. The great advantage and convenience of having a 
reliable reagent immediately available for use, particularly for night emergencies, can be appreciated.

Storage of Sensitized Cells Suitable for Coombs Control.-Washed, packed, sensitized red cells may be stored at $6^{\circ} \mathrm{C}$. in twice their volume of $0.5 \%$ formol-saline solution $(1.25 \mathrm{ml}$. formaldehyde diluted to $100 \mathrm{ml}$. in saline). The cells retain their freshness and give clear-cut Coombs reactions even after a week's storage. This simple practical procedure provides a suitable Coombs control available for any emergency.

\section{Albumin Tube Tests}

The rapidity with which agglutination takes place in Stratton's (1955) sandwich test clearly indicates that prolonged incubation is not essential. The short albumin method advocated by Lewis and Chown (1957) gives excellent results, but since it seemed that the important factor here might well be the high-speed centrifugation, a parallel series of "layered albumin tests" centrifuged after 10 minutes' and two hours' incubation respectively were compared with Lewis and Chown's method (Table II). The results clearly indicate that the 10-minute tests give equally good results compared with the longer incubation, and in fact in one instance (No. 15) the 10-minute test was definite whereas the corresponding two-hour test was doubtful.

The agglutinations in the "layered albumin tests" were not always quite so strong or clear cut as those obtained by Lewis and Chown's method. It is thought that this may be due to the fact that the final bovine albumin concentration in their method is $30 \%$ as compared to $20 \%$ in the layered

TABLE II

COMPARATIVE RESULTS OF LAYERED ALBUMIN AND THE SHORT ALBUMIN METHODS

\begin{tabular}{|c|c|c|c|c|c|}
\hline \multirow[b]{2}{*}{ Serum } & \multicolumn{2}{|c|}{ Antibody Titre } & \multicolumn{2}{|c|}{ Layered Albumin } & \multirow{2}{*}{$\begin{array}{c}\text { Short } \\
\text { Albumin } \\
\text { (Lowis and } \\
\text { Chown, 1957) }\end{array}$} \\
\hline & Saline & Albumin & $\begin{array}{c}10 \\
\text { Minutes }\end{array}$ & $\stackrel{2}{\text { Hours }}$ & \\
\hline $\begin{array}{r}1 \\
2 \\
3 \\
4 \\
5 \\
6 \\
7 \\
8 \\
9 \\
10 \\
11 \\
12 \\
13 \\
14 \\
15\end{array}$ & $\begin{array}{c}64 \\
16 \\
64 \\
256 \\
16 \\
\text { Nil } \\
\text {," } \\
\text {," } \\
, " \\
,, \\
\text {," } \\
\text { Minima }\end{array}$ & $\begin{array}{r}16 \\
8 \\
32 \\
512 \\
4 \\
32 \\
8 \\
64 \\
4 \\
8 \\
4 \\
2 \\
1 \\
<1 \\
\text { nsitization }\end{array}$ & $\begin{array}{l}4 \\
2 \\
4 \\
4 \\
4 \\
4 \\
1 \\
3 \\
4 \\
3 \\
3 \\
4 \\
3 \\
1 \\
M+\end{array}$ & $\begin{array}{l}3 \\
2 \\
3 \\
4 \\
3 \\
3 \\
2 \\
2 \\
3 \\
2 \\
2 \\
2 \\
2 \\
M_{+} \\
M_{-}:\end{array}$ & $\begin{array}{l}4 \\
3 \\
3 \\
4 \\
4 \\
4 \\
3 \\
3 \\
3 \\
4 \\
3 \\
4 \\
3 \\
2 \\
3 \\
2\end{array}$ \\
\hline
\end{tabular}

Key: $4=$ Single clump. $3=3-4$ large agglutinates. $2=$ several agglutinates. $1=$ Numerous fine agglutinates. $M=$ Microscopic reading. albumin (the diluent effect of serum excluded). It would seem therefore that, if albumin is used for compatibility testing, a 10-minute centrifugation test is to be preferred, since the results of tests on a wide selection of sera have clearly indicated that inhibition of agglutination by " zoning antibodies" is unlikely, and furthermore it is equally if not more sensitive than the usual two-hour incubation test.

\section{The Trypsin-saline Test}

For technical details the reader is referred to a previous article in this journal (Young, 1957). Further experience has shown that the $1.2 \%$ buffered trypsin reagent is quite stable and will store well at $6^{\circ} \mathrm{C}$. for four to five days, which is advantageous since it permits one to keep the reagent ready for use at night.

The results obtained by centrifugation after 20 minutes' incubation have been completely reliable in well over 1,500 cases. However, it is stressed that after 10 minutes this is not so. A subsequently performed trypsin-Coombs reaction is extremely sensitive and may be positive when both trypsin-saline and albumin tests are negative (Table III, serum 18).

The reliability of the albumin, trypsin-saline, trypsin-Coombs, and indirect Coombs compatibility tests after varying incubation periods are well shown in Table III. It should be particularly noted that in the group of cases with minimal sensitization the only completely reliable tests at 10 and 30 minutes are the trypsin-Coombs and indirect Coombs. In all other cases read at 30 minutes (with the exception of No. 16) the trypsin-saline test was positive, and all cases except the minimal sensitization group gave a positive 10-minute albumin centrifugation test.

\section{A Simple Practical Direct Matching Routine with a Suggested Procedure for Emergency Cross- matching}

The saline agglutination test at room temperature has been excluded for two reasons. Non-specific and specific cold agglutinins are encountered quite frequently and often cause unnecessary anxiety which may result in the rejection of the donor blood. Although their agglutinins react more strongly at lower temperatures, ABO incompatibility can be detected easily in the $37^{\circ} \mathrm{C}$. tubes when these are centrifuged at high speed before the final readings are made. For " good risk recipients," i.e., patients without a previous history of transfusions, pregnancies, or miscarriages, the cross-matching procedure does not need to be so comprehensive as for " bad risk cases" whose sera may contain rare immune antibodies, such as anti-Fy, which is only detectable by the Coombs 
TABLE III

COMPARATIVE RESULTS OF COMPATABILITY TESTS AFTER VARYING INCUBATION PERIODS

\begin{tabular}{|c|c|c|c|c|c|c|c|c|c|c|c|c|}
\hline \multirow[b]{2}{*}{ Sera } & \multicolumn{4}{|c|}{$10 \mathrm{Min}}$. & \multicolumn{4}{|c|}{$30 \mathrm{Min}}$. & \multicolumn{4}{|c|}{$120 \mathrm{Min}}$. \\
\hline & Albumin & $\begin{array}{l}\text { Trypsin- } \\
\text { saline }\end{array}$ & $\begin{array}{l}\text { Trypsin- } \\
\text { Coombs }\end{array}$ & $\begin{array}{l}\text { Indirect } \\
\text { Coombs }\end{array}$ & Albumin & $\begin{array}{l}\text { Trypsin- } \\
\text { saline }\end{array}$ & $\begin{array}{l}\text { Trypsin- } \\
\text { Coombs }\end{array}$ & $\begin{array}{l}\text { Indirect } \\
\text { Coombs }\end{array}$ & Albumin & $\begin{array}{c}\text { Trypsin- } \\
\text { saline }\end{array}$ & $\begin{array}{l}\text { Trypsin- } \\
\text { Coombs }\end{array}$ & $\begin{array}{l}\text { Indirect } \\
\text { Coombs }\end{array}$ \\
\hline $\begin{array}{c}\text { Group } \\
1 \\
2 \\
3 \\
4 \\
5 \\
\end{array}$ & $\begin{array}{c}\text { Albumin } \\
++ \\
+++ \\
+ \\
+++ \\
++\end{array}$ & $\begin{array}{c}\text { titres over } \\
- \\
++ \\
+ \\
+\end{array}$ & $\begin{array}{r}1: 32 \\
++ \\
+++ \\
++ \\
++ \\
+++\end{array}$ & $\begin{array}{c}++ \\
+++ \\
++ \\
++\end{array}$ & $\begin{array}{c}++ \\
+++ \\
+ \\
++ \\
++\end{array}$ & $\begin{array}{c}t \\
+++ \\
++t \\
- \\
+++\end{array}$ & $\begin{array}{c}+++ \\
++++ \\
++- \\
++++ \\
++++\end{array}$ & $\begin{array}{c}+++ \\
++++ \\
++- \\
++++ \\
++++\end{array}$ & $\begin{array}{c}++ \\
+++ \\
+ \\
++ \\
++\end{array}$ & $\begin{array}{c}+ \\
+++ \\
++ \\
+ \\
++\end{array}$ & $\begin{array}{l}+++ \\
+++ \\
+++ \\
+++ \\
+++\end{array}$ & $\begin{array}{l}+++ \\
++t \\
++t \\
++1 \\
+++\end{array}$ \\
\hline $\begin{array}{r}\text { Group } \\
6 \\
7 \\
8 \\
9 \\
10 \\
11\end{array}$ & $\begin{array}{c}\text { Albumi } \\
++ \\
++ \\
++ \\
+ \\
+ \\
++\end{array}$ & $\begin{array}{c}\text { titres } 1: 4 \\
= \\
\pm \\
\pm \\
\pm \\
=\end{array}$ & $\begin{array}{c}1: 16 \\
++ \\
++ \\
++ \\
++ \\
+ \\
+\end{array}$ & $\begin{array}{c}++ \\
+ \\
+ \\
++ \\
+ \\
+\end{array}$ & $\begin{array}{l}++ \\
++ \\
++ \\
++ \\
++ \\
++\end{array}$ & $\begin{array}{l}++ \\
++ \\
++ \\
++ \\
+ \\
+\end{array}$ & $\begin{array}{l}+++ \\
+++ \\
+++ \\
+++ \\
++ \\
+++\end{array}$ & $\begin{array}{c}++ \\
+ \\
++ \\
+++ \\
++ \\
+++\end{array}$ & $\begin{array}{l}++ \\
+ \\
++ \\
++ \\
++ \\
++\end{array}$ & $\begin{array}{c}++ \\
++ \\
++ \\
++ \\
+ \\
+\end{array}$ & $\begin{array}{c}+++ \\
+++ \\
+++ \\
+++ \\
++ \\
+++\end{array}$ & $\begin{array}{c}+t+ \\
t \\
+t \\
++t \\
++ \\
+++\end{array}$ \\
\hline $\begin{array}{c}\text { Group } \\
12 \\
13 \\
14 \\
15 \\
16\end{array}$ & $\begin{array}{c}\text { Album } \\
+ \\
+ \\
++ \\
++ \\
+\end{array}$ & $\begin{array}{c}\text { titres les } \\
- \\
- \\
= \\
+ \\
-\end{array}$ & $\begin{array}{c}\text { than } 1: 4 \\
++ \\
+ \\
++ \\
++ \\
+\end{array}$ & $\begin{array}{c}++ \\
+ \\
++ \\
++ \\
+\end{array}$ & $\begin{array}{c}+ \\
+ \\
++ \\
++ \\
+\end{array}$ & $\begin{array}{c}+ \\
\mathbf{M}+ \\
+ \\
+ \\
+\end{array}$ & $\begin{array}{c}+++ \\
++ \\
++ \\
++ \\
+\end{array}$ & $\begin{array}{c}+++ \\
++ \\
++ \\
+++ \\
++\end{array}$ & $\begin{array}{c}+ \\
+ \\
+\frac{1}{+} \\
+ \\
+\end{array}$ & $\begin{array}{l}++ \\
+ \\
++ \\
+\end{array}$ & $\begin{array}{c}+++ \\
++ \\
++- \\
+++ \\
+\end{array}$ & $\begin{array}{c}++ \\
++ \\
++ \\
++t \\
+\end{array}$ \\
\hline $\begin{array}{r}\text { Group } \\
17 \\
18 \\
19 \\
20\end{array}$ & $\begin{array}{l}\text { Minim } \\
= \\
= \\
= \\
=\end{array}$ & $\begin{array}{c}\text { sensitizat } \\
- \\
- \\
=\end{array}$ & $\begin{array}{c}+ \\
+ \\
++ \\
+\end{array}$ & $\begin{array}{l}+ \\
+ \\
+ \\
+\end{array}$ & $\begin{array}{l} \pm \\
- \\
\pm \\
=\end{array}$ & $\begin{array}{l} \pm \\
\overline{-}\end{array}$ & $\begin{array}{c}++ \\
+ \\
++ \\
+-\end{array}$ & $\begin{array}{c}+\rightarrow \\
+ \\
++ \\
+\rightarrow\end{array}$ & $\begin{array}{l}- \\
- \\
\div\end{array}$ & $\begin{array}{l}- \\
- \\
\overline{-}\end{array}$ & $\begin{array}{c}++ \\
+ \\
++ \\
++\end{array}$ & $\begin{array}{l}++ \\
+ \\
+- \\
++\end{array}$ \\
\hline
\end{tabular}

test. A direct matching routine is presented which is suitable for both classes of recipient. Emergency cross-matching is given special consideration.

Reagents for Trypsin-saline Test.-For further details the reader is referred to a previous publication (Young, 1957).

Stock Trypsin Solution.-A solution is made up of $3 \%$ crystallized trypsin (Armour Laboratories) in N/20 $\mathrm{HCl}$. This remains stable for four to six weeks stored in the refrigerator.

Buffered Trypsin for Tests.-A $1.2 \%$ solution is made from the stock trypsin using $p \mathrm{H} 7.7$ phosphate buffer solution as diluent. This dilute solution will remain stable for a few days if stored in the refrigerator.

Stored Sensitized Coombs Control Cells.-This control can be stored up to a week in $0.5 \%$ formol-saline.

Stored Diluted A.H.G. Serum.-As discussed previously.

\section{$\mathrm{pH} 7.7$ Phosphate Buffer :}
A. $\mathrm{Na}_{2} \mathrm{HPO}_{4} \cdot 12 \mathrm{H}_{2} \mathrm{O}$

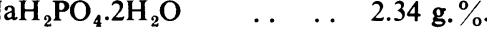

Mix 90.5 parts of A with 9.5 parts of $\mathrm{B}$ for use.

Direct Matching Routine.-Separate patient's serum and cells. Wash the cells twice and determine ABO and $\mathrm{Rh}$ groups. For $\mathrm{ABO}$ grouping a tube technique is preferred. The $\mathrm{Rh}$ group can be determined by the trypsin-saline method.

Wash donor cells twice in saline and make up to a $10 \%$ suspension. For each donor blood to be given set up the following two tube-tests and incubate them in a water-bath at $37^{\circ} \mathrm{C}$. for one hour.
(1) Trypsin-saline Test.-Two volumes patient's serum plus 1 vol. $10 \%$ donor cells plus 2 vol. $1.2 \%$ trypsin solution.

(2) Saline Agglutination Test.-Four volumes patient's serum plus 1 vol. $10 \%$ donor cells.

Centrifuge both at 1,500 r.p.m. for one minute. All doubtful or negative readings are checked microscopically.

In all antenatal patients, in women with previous pregnancies or abortions, and in any patient who has had a previous transfusion or is suffering from a haemolytic disorder, the Coombs and trypsin-Coombs tests should now be carried out if the trypsin-saline test is negative.

Wash the cells in tubes (1) and (2) three times in saline, finally pipetting off the supernatant saline completely leaving a dry button of cells. To each tube add 3 drops of a suitably diluted A.H.G. serum which has been checked against the stored sensitized Coombs control cells. Shake vigorously and stand at bench temperature for two minutes. Centrifuge at high speed for two minutes. Check readings microscopically if doubtful.

Emergency Cross-matching.-(1) Check patient's ABO group by the tile technique.

(2) Rapid Rhesus typing by Stratton's (1955) sandwich test is recommended.

(3) Set up tubes (1) and (2) as in the routine method. Incubate for a minimum of 10 minutes, preferably 20 minutes whenever possible. Read microscopically and always perform Coombs tests if negative. 
(4) While the above tubes are incubating perform a 10 -minute layered albumin test using a $50 \%$ saline suspension of donor cells thus: into a $3 \times 3 / 8$ in. test-tube place 3-4 vol. patient's serum, 1 vol. $50 \%$ donor cells, 2 vol. $30 \%$ bovine albumin. Shake vigorously for a minute and then allow to stand at bench temperature for 10 minutes. Centrifuge at 1,500 r.p.m. for two minutes. Read by rapid rotation of the tube when the packed cells will disperse into the supernatant if negative. Most positives give large solid clumps unless the antibody is very weak, in which case the agglutinates are finely dispersed. This is a valuable procedure as is clearly shown by the results given in Table II.

\section{Summary}

Following a discussion of certain practical points regarding the storage of diluted A.H.G. serum and Coombs positive control cells, which enables these to be kept immediately available for use in an emergency, a modified tube technique for the routine performance of Coombs tests is recommended as giving more reliable and sensitive results than the usual tile method.
The reliability of different compatibility tests after short incubation periods has been investigated and comparative results are shown in Table III.

Results are given in Table II which indicate clearly that a " 10 -minute centrifuged albumin test" is a valuable emergency procedure.

The introduction of the highly sensitive trypsinsaline test for direct matching is advocated and procedures for both routine and emergency compatibility testing are given.

I wish to acknowledge my gratitude to my colleagues, Dr. F. Marsh and Dr. I. Tuck, for their help and encouragement, and my thanks are also due to the senior technologist, Mr. A. Cooper, for his assistance in preparing the tables.

\section{REFERENCES}

Lewis, M., and Chown, B. (1957). J. Lab. clin. Med., 50, 494.

Marsh, F. (1957). Personal communication.

Mollison, P. L. (1951). Blood Transfusion in Clinical Medicine, p. 227. Blackwell Scientific Publications, Oxford.

Stratton, F. (1955). Brit. med. J., 1, 201.

Young, N. A. F. (1957). J. clin. Path., 10 (August), 236. 